\title{
POÉTICAS POLÍTICAS: AS ARTES PLÁSTICAS ENTRE O GOLPE DE 64 E O AI-5*
}

\author{
Political Poetics: plastic arts between \\ the 64 coup and the AI-5
}

\author{
Artur Freitas ${ }^{* *}$
}

\begin{abstract}
RESUMO
Os anos 60, especialmente depois do golpe militar de 1964, marcam um momento de grande radicalização política nos discursos artísticos. Após uma década de considerável hegemonia do projeto construtivo, o ressurgimento da figuração, num primeiro momento, e a posterior influência das neovanguardas internacionais, levariam alguns artistas brasileiros a abrirem espaço, em suas produções, às efervescentes questões sociais e políticas nacionais. Assim sendo, e tendo em vista a inserção estético-ideológica das artes plásticas entre o golpe de 64 e o Ato Institucional número 5, este artigo propõe-se, em linhas gerais, a fazer um levantamento sumário de alguns dos aspectos estéticos, políticos e institucionais mais relevantes da história da arte no Brasil daqueles anos. Quanto aos aspectos institucionais, como se dirá, esse período corresponde a um momento inicial dentro do processo de reestruturação econômica e de fomento do mercado brasileiro de bens simbólicos, fenômeno este que terá seu auge, pouco depois, no "milagre brasileiro". No que toca aos aspectos políticos, a repressão e a censura presentes desde os primeiros governos militares acabam de certo modo por incentivar os mais diversos tipos de contestação dentro dos meios culturais em geral e do artístico em particular. E, finalmente, no que toca aos aspectos estéticos, um certo posicionamento ideológico - tanto frente à institucionalização da cultura quanto frente ao autoritarismo de um regime opressor - surge reelaborado poeticamente sob a forma de linguagem, criando uma espécie de fusão entre todos esses aspectos conjunturais, ao que sugiro a noção de religação, que aqui surge como viés de interpretação.
\end{abstract}

Palavras-chave: arte e política; vanguarda; história da arte no Brasil.

* Este artigo é um excerto ligeiramente modificado da Dissertação de Mestrado: FREITAS, Artur. Arte e contestação: uma interpretação relacional das artes plásticas nos anos de chumbo - 1968-1973. Curitiba, 2003. 217 f. Dissertação (Mestrado em História) - Setor de Ciências Humanas Letras e Artes, Universidade Federal do Paraná.

** Doutorando em História pela Universidade Federal do Paraná, bolsista pela Capes. Mestre em História pela mesma instituição, também com bolsa Capes. 


\begin{abstract}
Especially after the military blow of 1964, the sixties mark a moment of great political radicalism in the artistic discourse. After a decade of considerable hegemony of the constructive project, two reasons make brazilian artists create works open to the main social and political national subjects: in a first moment, the resurgence of figuration and, later, the influence of international neo-avantgardes. So, considering the aestheticideological situation of the arts between the blow of 64 and the Institutional aspects Act number 5, this article intends to do a synthetic rising of some aesthetic, political and institutional aspects more important in brazilian art history of those years. Regarding to the institutional aspects, that period corresponds inside to an initial moment of the process of economical restructuring and fomentation of the brazilian market of symbolic goods, phenomenon that will be in the peak, after, in the "brazilian miracle". Regarding to the political aspects, the repression and the censorship existent from the first military governments - they motivate the most several reply types inside in general of the cultural ways and of the artistic way in matter. And, finally, with relationship to the aesthetic aspects, a certain ideological positioning - it so much front to the institutionalization of the culture as front to the authoritarianism of an oppressor regime aestheticly restored appears under the language form, appearing a type of union among all those aspects of the situation. And, if I suggest the religation to name that union, I suggest it because that notion here appears as interpretation access.
\end{abstract}

Key-words: art and politics; avant-garde; art history in Brazil.

Entender o lugar das artes plásticas nos anos 60 - e no Brasil elas já são, a essa altura, uma instituição-é, de saída, uma contradição, um problema de identidade. Sobretudo nesses anos, a própria noção genérica de "artes plásticas" é o maior sintoma desse problema. Gêneros milenares como a pintura e a escultura são repensados, questionados $\mathrm{e}$, em alguns casos, literalmente execrados. A colagem cubista, o ready-made e as merz dadaístas são teleologicamente resgatados e fundidos aos novos meios e conceitos, ao corpo, ao processo e ao tempo, numa intensa sucessão de "ismos". A explosão das linguagens e suportes é um fato internacional nessa década. ${ }^{1}$ Testar os limites que

1 "Nos inícios dos anos 60 ainda era possível pensar nas obras de arte como pertencentes a uma de duas amplas categorias: a pintura e a escultura. As colagens cubistas e outras, a performance futurista e os eventos dadaístas já haviam começado a desafiar este singelo ‘duopólio', e a fotografia reivindicava, cada vez mais, seu reconhecimento como expressão artística. No entanto, ainda persistia a noção de que a arte compreende essencialmente aqueles produtos do esforço criativo humano que gostaríamos de chamar de pintura e escultura. Depois de 1960 houve uma decomposição das certezas quanto a esse sistema de classificação. Sem dúvida, alguns artistas ainda pintam e outros fazem aquilo a que a tradição se referia como escultura, mas estas práticas agora ocorrem num espectro mais amplo de atividades" (ARCHER, 2001, p. 1). Por outro lado, embora esse seja um dado concreto da arte nos 60, convém lembrar com Ronaldo Brito que o "rompimento das categorias tradicionais de belas-artes (...) começa com a própria arte moderna” (BRITO, 1999, p. 87). 
separam a arte da vida é a base desse jogo. A efetiva institucionalização de um espaço social próprio à arte é contraposta tanto à cultura de massa quanto à violência das novas vanguardas. ${ }^{2} \mathrm{O}$ crescente afluxo das massas às Bienais de arte é proporcional à incompreensão generalizada da estética contemporânea. E em meio a uma diversidade expressiva fabulosa, os problemas gerais, enfim, de uma sociedade de consumo urbanizada e socialmente desigual, bem como os problemas específicos de uma sociedade brasileira oprimida pelos desmandos da ditadura militar, tornam-se conteúdos freqüentes à arte. A contestação (via novas figurações e vanguardas), se é um dos retratos possíveis do momento, talvez, aqui, também funcione como caminho interpretativo.

\section{Aspectos institucionais da produção cultural brasileira}

Durante os anos 60 e 70 - como não é segredo - as esferas culturais brasileiras, em sua intrincada diversidade, tiveram parte ativa e contraditória nas transformações históricas do país, fosse na elaboração e divulgação de um complexo ideário de oposição geral e pública ao regime militar, fosse na formação coletiva de um "olhar" revigorado pelos novos medium, ou fosse ainda, por outro lado, pela participação fundamental no processo de consolidação de um mercado ampliado de bens simbólicos. Justamente nesse período, o Estado, sobretudo o Estado autoritário, foi responsável, como já se convencionou dizer, por uma eficaz modernização conservadora no país - expressão que tenta resumir duas importantes faces ideológicas do poder: de um lado a consolidação do antigo projeto de industrialização do Brasil - a modernização (que inclui também, entre outras coisas, a ampliação do setor de serviços, a urbanização e a padronização de certos hábitos, inclusive os de consumo) -, e de outro, sob o aspecto conservador, uma gradativa e por fim violenta intolerância às ações e às idéias opositoras de qualquer espécie. Tanto numa perspectiva quanto noutra, as esferas de produção cultural, sobretudo as massivas, avançavam ao centro das questões políticas, econômicas e ideológicas, conquistando espaços e pressões de toda sorte. As alianças entre

2 Para uma definição clássica de "vanguardas históricas", veja-se Peter BÜRGER (1993, p. 67), que com ADORNO (1982, p. 178) guarda em comum tanto um certo saudosismo frente ao "heroísmo" das primeiras vanguardas quanto uma certa descrença na retomada vanguardista dos anos 60 e 70 . Para uma visão igualmente lúcida embora mais otimista das neovanguardas, leia-se a obra de Gianni Vattimo, especialmente: VATTIMO, 2002, p. 40-52. E para uma rápida distinção entre vanguarda lato sensu e stricto sensu, cf. FREITAS, 2003, p. 1-13. 
grandes conglomerados empresariais (como rede Globo, Editora Abril e os maiores jornais diários) e os interesses mais amplos da política pública foram decisivas na consolidação de uma poderosa indústria cultural, tornando relevante a compreensão das "relações de interesse que os proprietários e responsáveis por esses conglomerados mantêm com os dirigentes políticos e governamentais em torno da concessão de estações de rádio e televisão e da ‘comercialização' no paralelo de espaços na mídia” (MICELI, 1994, p. 42). O Estado autoritário, desse modo, fornece notáveis condições políticas e infraestruturais para o avanço nos principais setores massivos da produção cultural, como o mercado fonográfico, o editorial, a publicidade e a indústria televisiva, que nesses tempos comportam elevados índices de expansão sociogeográfica e de crescimento econômico. ${ }^{3}$

Seguindo as sínteses históricas do sociólogo Renato Ortiz:

o Estado autoritário permite consolidar no Brasil o "capitalismo tardio". Em termos culturais essa reorientação econômica traz consequiências imediatas, pois, paralelamente ao crescimento do parque industrial e do mercado interno de bens materiais, fortalecese o parque industrial de produção de cultura e o mercado de bens culturais (ORTIZ, 1991, p. 114).

E é, desse modo, o próprio Ortiz quem afirma insistentemente que a ideologia pós-64 não se voltou exclusivamente à repressão, tendo da mesma maneira, em termos gerais, orientado seus esforços ao robustecimento de um sólido mercado consumidor nacional, o que, por sua vez, teria efeitos consideráveis nas diversas áreas da produção cultural brasileira (ORTIZ, 1985). Assim sendo, em resumo, quanto às bases tanto socioeconômicas quanto ideológicas da atividade cultural no Brasil durante o período militar, é preciso ter em vista o surgimento de um curioso fenômeno histórico: a coexistência

3 É durante os anos 60, por exemplo, que surgem as maiores agências de publicidade do país (Mauro Salles, MPM, DPZ, Propeg etc.), bem como é nessa década que a publicidade tanto ganha a universidade (são criadas as escolas de comunicação: ECA - 1966, Álvares Penteado - 1967, UFRJ - 1968), quanto passa a defender seus interesses por meio de associações de profissionais de comunicação (Associação Brasileira de Anunciantes - 1961, Conselho Nacional de Propaganda - 1964, Federação Brasileira de Marketing - 1969). É durante esses anos ainda que multiplicam-se os institutos de pesquisas mercadológicas (Gallup - 1967, IVC - 1961, Audi-TV - 1968, Simonsen - 1967, LPM - 1969 etc.) e que a televisão se consolida como veículo de massa. Em 1965 não somente é criada a Embratel, que inicia toda uma política modernizadora para as telecomunicações, como também o Brasil se associa ao sistema internacional de satélites (Intelsat). Em 1966 cria-se o Instituto Nacional de Cinema e o Conselho Nacional de Cultura; e em 1967 a Tupi tira do ar a TV Vanguarda, encerrando o ciclo do teleteatro e inaugurando-se a era da hegemonia da telenovela. O Ministério de Comunicações é criado no mesmo ano. Cf. ORTIZ, 1991; NAPOLITANO, 2001a. 
entre uma pesada repressão político-ideológica e uma intensificação sem precedentes na produção e difusão nacionais de bens culturais, fruto direto de uma modernização conservadora das indústrias da cultura, da regulação e do incentivo do Estado e da aliança com o grande capital.

Nos circuitos de distribuição restrita, como o meio social das artes plásticas, a situação geral, se por definição é diferente daquela da cultura de massa, não o é de todo, uma vez que boa parte dos fardos e das benesses do governo autoritário também desabou, mesmo que à sua maneira, sobre o campo da arte. É evidente que ali não se presenciou o mesmo volume de investimentos públicos e privados que estava presente em áreas de extenso alcance coletivo como a televisão, a publicidade ou a música popular. Mesmo nos poucos grandes eventos como a Bienal Internacional de São Paulo, que chegava a receber entre 300 e 400 mil visitas durante os meses de exposição, os números surgem bastante acanhados quando comparados aos da produção de massa. A particular irreprodutibilidade da obra de arte, a individualidade que caracteriza a produção do artista plástico (contraposta à coletividade produtiva do cinema, do teatro, da música e da produção televisiva) e, principalmente, a vontade geral de distinção cultural que se espraia com facilidade pelo meio de arte, tudo isso junto, por certo, não facilita uma eventual permeabilidade do campo artístico aos demais universos da cultura. $\mathrm{O}$ que não impede, todavia, que ainda assim se perceba que durante os anos 60 tenha ocorrido, como em outras áreas, uma certa continuidade no processo de institucionalização específica das artes plásticas - processo esse iniciado, sobretudo, em fins dos anos $40 .{ }^{4}$

A partir das doações do acervo do MAM-SP e das coleções particulares de Francisco Matarazzo Sobrinho e Yolanda Penteado, a USP, em 1963, cria o Museu de Arte Contemporânea (MAC-USP), já na época "a maior reunião de objetos de arte do século XX" - como dizia Walter Zanini -, o que permitiu ao meio artístico brasileiro, através de sistemáticas mostras itinerantes, um ganho significativo no acesso às informações artísticas mais recentes. As intensas atividades museológicas do Museu de Arte de São Paulo (Masp) e do Museu de Arte Moderna do Rio de Janeiro (MAM-RJ) foram igualmente fundamentais.

4 Em fins dos anos 40 e início dos 50 tem início uma institucionalização cultural sem precedentes no país: fundam-se o maior espaço museológico brasileiro: MASP, 1947; o mais importante museu de arte moderna: MAM-SP, 1948; e a mais relevante mostra internacional de artes no Brasil: a Bienal de São Paulo, 1951; concomitantemente a outros marcos da cultura de massa: Vera Cruz (1949), televisão em São Paulo (1950) e no Rio de Janeiro (1951), Teatro Brasileiro de Comédia (1948), introdução do LP (1948), I Encontro dos Empresários do Livro (1948), normas-padrão para o funcionamento das agências de publicidade (1949), Editora Abril (1950), Cásper Líbero, primeira escola de propaganda (1951), aumento da publicidade permitida no rádio de 10 para 20\% da programação diária (1952) etc. Cf. ORTIZ, 1985; 1991; 1994; AMARAL, 1984; ZANINI, 1983; NAPOLITANO 2001a; DURAND, 1989. 
Os salões de arte moderna, em sua maioria consagratórios (destinados basicamente à avaliação e premiação de artistas e obras), difundem-se pelo país ao lado de novas mostras de destaque como a Exposição Jovem Desenho Nacional, Jovem Gravura Nacional e Jovem Arte Contemporânea, todas do MAC-USP (ZANINI, 1983, p. 730-732). A Bienal de São Paulo, tornada Fundação logo no começo da década, segue sendo o principal evento artístico do país e um dos maiores do planeta.

Sobre a afluência de recursos humanos nas artes plásticas, merecem destaque o crescente acesso pré-escolar à "arte-educação" e o aumento em geral da escolarização universitária durante os últimos anos, dados que juntos fomentam a criação de um expressivo contingente profissional ligado às artes visuais, além de auxiliar na formação de um público cultivado mais extenso. Um bom índice do alargamento no efetivo de artistas e de público no país durante esses anos pode ser percebido na considerável expansão do mercado editorial voltado especificamente às publicações sobre artes plásticas. ${ }^{5}$

Outro aspecto relevante a se considerar do ponto de vista institucional - embora talvez mais como uma contrapartida -é o da precariedade do mercado brasileiro de arte até os anos 60. Mesmo na "etapa eufórica" desse mercado (C. 1970-1975), os indicadores de negociações e investimentos em objetos de arte não permitem generalizar a extensão desses benefícios a círculos mais largos que aqueles conquistados por um pequeno contingente de artistas renomados, e isso sem contar que o subseqüente arrefecimento histórico nos negócios de arte (C. 1975) sequer permitiu que se consolidasse um mercado de arte mais ou menos estável no Brasil antes dos anos 80. Durante a década de 60, portanto, o mercado de arte é ainda bastante incerto no país, mesmo nos principais centros urbanos (DUARTE, 1998, p. 37), embora essa década, em comparação com as décadas precedentes, tenha assistido um surgimento volumoso de novas galerias - ainda que semiprofissionais em sua maioria (DURAND, 1989). A figura do marchand, inexistente antes dos anos 60, guarda nessa década ainda

5 Entre 1960 e 1970, o mercado brasileiro de revistas dobrou em tiragem global indo de 104,8 para 193,7 milhões de exemplares. Nesse mesmo período, o número de publicações direcionadas especificamente às artes plásticas cresce na mesma medida: vários gêneros da cultura erudita ganham circulação mais efetiva ou aparecem popularizados em fascículos. Em 1967 e 1972 a Abril Cultural lança a coleção Gênios da pintura, com tiragens respectivas de 144 e 69 mil exemplares no primeiro número. Publicações similares foram lançadas por outras editoras: Biblioteca de arte, Editora Três (1973-1975); Mundo dos museus, Codex (1978); e História da arte, Salvat (1978) (informações em DURAND, 1989, p. 178-179). A imprensa dos anos 60 e 70, a crer em Walter Zanini, "com um colunismo de altos e baixos, continuou a ser a principal via de divulgação artística. Entre as principais publicações especializadas, e conteúdo diversificado, podem ser citadas Forma, Arte: hoje, Mirante das Artes, Revista GAM, Malasartes, Arte Vogue, Vida das Artes, quase todas de vida efêmera" (ZANINI, 1983, p. 733); sem contar Arte em Revista. 
a romântica imagem de amante e estimulador das artes (Jean Boghici, Ceres Franco), imagem oposta, portanto, ao ambiente de grande especulação financeira que reinaria, em alguns momentos, nos anos 70 (MORAIS, 1995, p. 44).

Não obstante, em detrimento desse conjunto de fatores, é difícil captar o que foram esses anos 60, sobretudo no turbilhão das artes plásticas, se nos fixamos somente em seus aspectos institucionais. É evidente que, de uma forma ou de outra, tão vultuosas alterações no perfil socioeconômico do país e das áreas culturais são importantes e, provavelmente, ecoaram na mais enclausurada e autônoma das poesias. A consolidação da televisão, a crescente divisão de trabalho e profissionalização das áreas culturais, a formação de um mercado simbólico de porte nacional, o aumento na disponibilidade de informações, o agigantamento da imprensa, a integração internacional via satélite e a multiplicação dos salões, dos museus, das galerias e das pinacotecas eram causas poderosas demais para não cultivarem efeitos. Entretanto, ocorre que esses grandes fenômenos, por maiores que fossem, não podiam prever nem controlar seus múltiplos ecos sociais, culturais ou mesmo estéticos - e principalmente os estéticos -, sobretudo se levamos em conta que os produtos oriundos dos universos mais autocentrados da cultura normalmente mantêmse em relação mais direta com os outros produtos desses mesmos universos do que propriamente com o conjunto da sociedade. Tais meios restritos, por uma questão sociohistórica de julgamento entre pares (conforme os conceitos de campo artístico, de habitus e de autonomia propostos por Pierre BOURDIEU (1998; 1989), tendem a referir-se mais aos seus debates internos do que propriamente ao mundo da economia ou da luta de classes, sobretudo no campo das artes plásticas, "que, junto com a literatura, constitui o núcleo mais resistente às transformações contemporâneas" (CANCLINI, 2000, p. 62). Nessa linha de raciocínio, inclusive, não foi outro senão o próprio Bourdieu quem chegou a perceber que "a realização mais acabada do modelo da dinâmica que caracteriza um campo tendente ao fechamento, reside na história da pintura" (BOURDIEU, 1998, p. 115).

Assim, se me parece, de algum modo, que as manifestações artísticas tanto se relacionam com a história quanto também participam de sua constituição, parece-me igualmente evidente, entretanto, que essas manifestações guardam conexões muito sutis e peculiares com seu tempo, por vezes tão sutis que só se desvelam quando imersas no nível específico da obra.

Desse modo, por exemplo, é preciso muito mais do que boa vontade para entender porque depois de quase dez anos de predomínio da abstração (construtiva e informal) as artes plásticas, nesses anos, exploram a figura, admitem 
o realismo, abraçam Duchamp e permeiam-se à política. Qualquer resposta singular ou monocausal é insuficiente e mesmo ingênua. Compreender assim os debates específicos da arte é tão ou mais importante que descobrir os eventuais macro-condicionamentos heterônomos que porventura pressionam a atividade artística. E aí encontramos o maior desafio metodológico deste artigo.

A questão, em suma, não consiste em transportar mecanicamente os debates políticos e as pressões econômicas, sem dúvida existentes, à esfera da arte, e tampouco apropriar-se dos discursos da arte para desvendar os discursos da ideologia, mas sim, antes, consiste em interpretar certas sutilezas que engendram e viabilizam, em cada contexto, e ao nosso olhar, as especificidades de uma cultura artística, ou seja, de um espaço dinâmico mais ou menos restrito à arte, onde se organizam os sistemas de referência, os quadros de valores e as normas de relacionamento, a partir do qual os esquemas formativos se dispõem, bem como os esquemas perceptivos de aquisição. Sendo assim, e para melhor compreender, no Brasil, como se deram certas transformações na cultura artística durante os primeiros anos do regime militar, sugiro que se tenha em mente, mesmo que de maneira sucinta, as principais forças estético-ideológicas que despontavam no cenário brasileiro desde inícios dos anos 60 .

\section{Inícios dos anos 60: preocupação política e diversidade cultural}

Em 1960, ao menos nas duas maiores cidades brasileiras, já é considerável a massa crítica envolvida diretamente em questões específicas de arte. O neoconcretismo, dissidência carioca do movimento concreto desde $1959,{ }^{6}$ aglutina à sua volta as principais produções e discussões do período. $\mathrm{O}$ espaço da pintura parece tendente a derramar-se pelo espaço do mundo real. A relação figura-fundo, o uso da moldura na pintura e da base na escultura e inclusive a própria separação tradicional entre pintura e escultura, tudo é revisto e parece

6 Data da publicação do Manifesto Neoconcreto (JB, 22 mar. 1959, apud BRITO, 1999, p. 10-11), escrito por Ferreira Gullar e assinado pelos seguintes artistas: Franz Weissmann, Amílcar de Castro, Lygia Clark, Lygia Pape, Reynaldo Jardim e Theon Spanudis. Outros artistas como Hélio Oiticica, Willys de Castro, Hercules Barsotti, Décio Vieira e Osmar Dillon também pertencem ou pertencerão ao grupo (GULLAR, 1999, p. 244). 
perder o sentido. Ao rigor teórico gestaltista e semiótico do concretismo sobretudo o paulista defendido pelos irmãos Campos e Décio Pignatari - os neoconcretistas respondem com a consideração simbólica do corpo, com a subjetividade fenomenológica de Merleau-Ponty e com o utópico projeto de reintegração da arte à vida. Os últimos resquícios da espacialidade profunda e metafórica pretendem-se eliminados. A arte parece pronta a participar do cotidiano que lhe rodeia. A representação, enquanto arranjo de elementos sobre um fundo simbólico, é substituída pela simples presença corpórea da obra, o que não é pouco à compreensão da arte no Brasil ou em qualquer lugar. Surgem os Relevos espaciais, de Hélio Oiticica, o Livro da criação, de Lygia Pape e os Casulos e os Bichos de Lygia Clark, objetos simplesmente apresentados à experiência e independentes da tradicional tarefa de mediação simbólica; ou ainda, nas palavras de Ferreira Gullar, autênticos não-objetos oferecidos à percepção. ${ }^{7}$

A experiência neoconcreta, no entanto, é relativamente efêmera enquanto "movimento" artístico (data limite: 1960), mas de qualquer forma ela é forte o suficiente para desviar e, portanto, renovar o debate estético no país. Em pouco tempo seus principais participantes abrem-se tanto a outras frentes poéticas quanto às novas questões estético-ideológicas que vão surgindo.

Os anos conturbados do governo João Goulart (1961-1964) são solo fértil ao brotar de novos debates sobre a arte e a produção cultural em geral. Em paralelo tanto à crescente influência do expressionismo abstrato norte-americano e do informalismo europeu quanto às inovadoras propostas estéticas de artistas como Waldemar Cordeiro e Oiticica, surgem os primeiros movimentos de cultura popular, "resultantes do fortalecimento da idéia de uma cultura engajada na política" (ZANINI, 1983, p. 730). No universo das artes plásticas, portanto, se de um lado essa pluralidade de posicionamentos desde já é o grande apanágio que marcaria toda a produção subseqüente nessa década, de outro, a mais densa novidade desses anos é justamente o recrudescimento nos debates acerca

7 A Teoria do não-objeto talvez tenha a sido a primeira grande contribuição estética de uma teoria da arte pensada no Brasil. Numa linguagem límpida e direta, Ferreira Gullar afirmava que a pintura e a escultura - mesmo as não-figurativas como as concretistas (ou as de Malevitch ou Mondrian) - ainda mantinham em si a contradição representativa espaço-objeto. Nessa pintura tradicional, por exemplo, os elementos dispostos na tela, mesmo que não reconhecíveis, ainda caminhavam sobre um fundo ficcional e pictórico, ao passo que num não-objeto a obra seria uma pura presença que se daria sobre o fundo do mundo real, confundindo-se, portanto, com os demais objetos do cotidiano. A única diferença entre um não-objeto e um objeto cotidiano seria que o segundo, ao contrário do primeiro, "se esgota na referência de uso e sentido". Ou seja, embora essa teoria sustente-se em conhecidas premissas da estética moderna (a separação iluminista entre forma e função e o "desinteresse" kantiano inerente ao juízo do belo), ela inova o debate no Brasil ao propor uma estética da presença, em desfavor de uma simples estética da forma plástica. 
da função social e política da arte e dos artistas na sociedade brasileira. O próprio Ferreira Gullar revê seus posicionamentos ideológicos e passa a defender a infiltração do critério político e participativo nas produções culturais. Conforme Aracy Amaral, seria justamente nesse período, por exemplo, que teriam surgido

os primeiros documentos teóricos, inexistentes, nesse nível, nos anos 50, em torno à participação do intelectual e do artista na problemática social de seu tempo, seja em termos de "artistas de elite" versus "artista popular revolucionário", seja com referência à assunção da arte de conteúdo, a arte política como único caminho para o artista de seu tempo, a par da preservação necessária da qualidade de sua produção (AMARAL, 1984, p. 318).

Nesses tempos, e apesar de ser largamente debatida e geralmente colocada em oposição a algo como "arte de elite", a noção de "arte popular" (ou "cultura popular"), em geral, não corresponde nem à arte produzida pelo "povo", nem àquela massivamente produzida e distribuída para ele, mas sim a uma atividade, a priori, política desenvolvida por intelectuais e artistas engajados no esclarecimento e na conscientização das classes menos favorecidas. ${ }^{8}$ Era o tempo da mais ativa atuação dos Centros Populares de Cultura - entidades político-culturais socialistas, semi-autônomas e ligadas à União Nacional dos Estudantes (CPC da UNE). Com base num critério de pedagogia política, os CPCs, desde o início, privilegiaram as manifestações artísticas que pudessem aumentar as chances de contato com o "proletariado", acreditando que uma eventual "democratização da cultura" pudesse tanto desencastelar o ato estético de suas torres de marfim quanto estimular a consciência criadora e, logo, desalienante das massas. O uso da palavra e a recepção coletiva ampliada fizeram do teatro e da música popular os dispositivos preferidos pelos cepecistas na tarefa de disseminar mensagens "revolucionárias" nas favelas, praças públicas e portas de fábricas. As artes plásticas - é claro , quando pensadas nesse contexto, mostravam-se basicamente inaptas às exigências coletivistas do $\mathrm{CPC}$, apenas conseguindo uma atuação efetiva

8 O conceito de cultura popular, nesses tempos é dado como uma atitude política intelectual que não tem correspondência com os "mores materiais e simbólicos do homem rústico, sertanejo ou interiorano, e do homem suburbano ainda não de todo assimilado pelas estruturas simbólicas da cidade moderna" - conforme uma definição de cultura popular arriscada por Alfredo BOSI (1992, p. 309). 
secundária, com resultados políticos inexpressivos e resultados artísticos normalmente pouco prestigiados. ${ }^{9}$

Não obstante, é preciso dizer que a diversidade (de manifestações, meios e suportes) ainda é a tônica do meio artístico brasileiro - e o ano de 1963 é a comprovação desse fato: no mesmo instante em que Ferreira Gullar (então presidente do CPC) publica seu Cultura posta em questão, tanto criticando o "isolamento arte-purista" quanto enaltecendo uma "arte em termos de prática política" (GULLAR, 1963), o abstracionismo informalista é consagrado na VII Bienal de São Paulo e no Salão Nacional de Arte Moderna. No mesmo ano a Galeria Bonino expõe o grupo argentino Otra Figuración, que viria a exercer grandes influências em artistas como Antonio Dias e Rubens Gerchman.

\section{O golpe de 64 e a resposta dos meios culturais}

Depois de 1964, contudo, a situação se altera ligeiramente, se não em termos de pluralidade artística, mas em termos do relacionamento entre arte e política. Quando sobreveio o golpe militar, em abril daquele ano, foi grande a derrota das esquerdas. A imprevisibilidade da ação militar fundava-se num conhecido lapso estratégico: o apoio mútuo entre Partido Comunista (PCB) e João Goulart. "Estava na lógica das coisas que o PC chegasse à soleira da revolução confiando no dispositivo militar da Presidência da República" (SCHWARZ, 1978, p. 75). E, como grave revés político aos dispositivos de esquerda, uma das primeiras iniciativas do governo Castelo Branco foi cortar as poucas pontes existentes entre o movimento cultural e as massas, evitando que a intelectualidade socialista do país fomentasse qualquer espécie de

9 “Colaboram com o CPC na área de artes plásticas, entre outros, Júlio Vieira, Eurico Abreu, Delson Pitanga e Scliar. Segundo Júlio Vieira, o CPC, no Rio, deu mais ênfase ao cinema, ao teatro e à literatura, considerando as artes plásticas apenas uma 'linha auxiliar'. Os artistas vinculados ao CPC participam da campanha de Sérgio Magalhães ao governo do Rio de Janeiro, pintando faixas, carros, retratos, etc" (MORAIS, 1995, p. 276). Assim sendo, em detrimento das exíguas produções plásticas cepecistas, é provável que as principais contribuições do CPC ao campo das artes plásticas tenham vindo dos textos de Ferreira Gullar, a essa altura convertido à ideologia política dos Centros. Pode se dizer, aliás, que o então recém saído da experiência neoconcreta, o poeta e crítico de arte maranhense, personifica mesmo, por esses anos, o drama daquela conhecida noção bermaniana de "cisão fáustica". O reencontro com o "popular" e o ensaio frustrado de síntese entre "arte popular" e "arte de vanguarda" - numa tentativa desesperada de ação política "participante" - acompanham os passos de seus primeiros cargos culturais: primeiro, em 1961, quando Gullar assume a direção da Fundação Cultural de Brasília, e posteriormente quando se torna o segundo presidente do CPC do Rio de Janeiro, depois de Carlos Estevão Martins. 
"contragolpe" entre os "operários, camponeses, marinheiros e soldados" (p. 62). Assim, nessa vaga, qualquer manifestação artística considerada subversiva pelos militares e que almejasse levar suas idéias a público, especialmente às classes populares, deveria ser suprimida a qualquer preço. Calaram-se então, junto às vozes de sindicalistas e de políticos indesejados, as vozes ligadas ao CPC, entidade já sabidamente envolvida com a militância político-cultural de esquerda.

Dessa forma, uma vez cortadas as pontes entre arte revolucionária e povo, o engajamento político nas artes, entendido cada vez mais como uma noção genérica de cultura de oposição, se vai aos poucos restringindo a um consumo essencialmente "classe média, jovem, universitário e de esquerda" em que pese a frouxidão dessa conhecida generalização. ${ }^{10}$ Dentro desses limites, todavia, e em decorrência tanto de um sentimento generalizado de derrota das esquerdas quanto de uma opressão significativa imposta pelo novo regime, intensificam-se as discussões sobre o lugar da arte e do artista na sociedade brasileira, bem como as discussões a respeito de quais seriam as novas formas artísticas condizentes com os novos tempos. Em pleno período repressivo, portanto, cria-se todo um complexo circuito de consumo para a "cultura de oposição", o que leva ao sociólogo Roberto Schwarz, ainda no calor da hora, a reconhecer nessa situação uma certa anomalia que proclamou como sendo "o traço mais visível do panorama cultural brasileiro entre 64 e 69”. Já na época, inclusive, ele afirmava que "Apesar da ditadura da direita, há relativa hegemonia cultural da esquerda no país"11.

$\mathrm{E}$ de fato, no que diz respeito às produções culturais realizadas entre o golpe de 64 e o Ato Institucional n. 5 (o AI-5, de 13 de dezembro de 1968), um certo sabor contestatório - variável conforme o momento e a forma de expressão - pode ser colhido com certa facilidade. Destacavam-se, sobretudo, as manifestações mais voltadas à fruição coletiva, como o cinema, o teatro e a música popular, que propiciavam uma certa cumplicidade jovem e pública frente à grande festa da indignação.

Já em fins de 1964 surge o mitológico espetáculo Opinião, criado pelo grupo homônimo cujos integrantes vinham, muitos, da dissolução do CPC. No ano seguinte, Glauber Rocha escreve o manifesto Estética da fome, o Teatro de Arena interpreta Arena canta zumbi, de Boal e Guarnieri, enquanto Chico

10 Já apontada por Marcos Napolitano (2001b, p. 103-124).

11 SCHWARZ, 1978, p. 62. Essa noção de "anomalia" é também cultivada por outros estudiosos desse período como Daisy Peccinini, Aracy Amaral, Heloísa Buarque de Hollanda e Marcelo Ridenti, embora este último tenha algumas restrições quanto ao uso, nesse caso, da noção gramsciana de "hegemonia". 
Buarque compõe a canção Pedro pedreiro. De Ferreira Gullar e Vianinha, a peça Se correr o bicho pega, se ficar o bicho come (Teatro Opinião) é de 1966. E de 1967 é a canção Domingo no parque, de Gil e o livro Quarup, de Antonio Callado. No ápice dessa cadeia, 1968 aparece como o ano chave, onde a onda de contestação e resistência surge proporcional à violência policial do regime. Explode o tropicalismo, canta-se o "hino" Pra não dizer que não falei das flores, de Geraldo Vandré e espancam-se os atores da peça Roda viva, texto de Chico Buarque e direção de Zé Celso: a linha dura, dedo em riste, indica o endurecimento iminente do AI-5. Restam, aos mais inquietos, o exílio, a censura prévia, a autocensura, a metáfora crítica, a prisão e o medo.

As artes plásticas, por seu lado, deram um encaminhamento bastante específico a essas questões, um encaminhamento, em geral, diferente daqueles realizados pelas outras áreas de expressão artística - e por diversas razões. Em primeiro lugar porque o engajamento político explícito não era recorrente nas obras dos artistas plásticos, mesmo nos momentos mais duros da repressão. $\mathrm{O}$ medo do servilismo intelectual num campo cultural, àquela altura consideravelmente elitizado e autônomo, e o quase irrefreável processo histórico de incompatibilização das produções artístico-visuais com os aspectos literários da narração, sem dúvida pouco estimulavam o engajamento explícito nas artes plásticas. O excesso de transparência na informação ideológica da manifestação de arte, portanto, soava ou como panfleto, ou como publicidade ou como ilustração, as três piores maldições do campo artístico. O rebaixamento da obra em favor da clareza de alguma mensagem política ainda podia remeter ao realismo socialista - e era falta grave. O radicalismo, naquele período de extrema experimentação na arte, não estava no tema, no assunto tratado. E mesmo nos casos onde a preocupação social ou política era evidente, a manifestação artística deveria se sustentar, sobretudo, pela sua condição estética - e não pela sua condição de eventual artefato político -, e ser julgada pelos pares. Portanto, se durante aqueles anos o político, num sentido amplo, e sob a mirada do ético, atravessava toda a problemática da inserção da arte na sociedade brasileira, nem por isso a referência imediata aos problemas dessa sociedade se tornou regra ou compôs-se como programa poético de grandes parcelas da comunidade artística.

Seguindo esse eixo, cabe também lembrar, como outra razão das especificidades estético-ideológicas das artes plásticas, que tanto o restrito alcance público das produções dos artistas plásticos quanto o habitual elitismo de suas instituições não ajudavam a crer numa participação mais efetiva das artes plásticas em algum grande projeto de transformação social. 
E ainda, como mais um motivo possível, é preciso também notar que a produção cultural nas artes plásticas, enquanto resultante em peças normalmente únicas e irreprodutíveis, servia, na qualidade de mercadoria de luxo, como signo de distinção às elites, como uma forma de diferenciação social frente aos produtos de farto alcance e reprodução dos mass-media. Desse modo, mesmo que aceitemos que nesses tempos, nas diversas produções dos artistas plásticos, grosso modo, tenha havido uma certa abertura aos problemas políticos e sociais brasileiros, é imprescindível ter em mente que essa porosidade heterônoma só possui sentido se compreendida a partir das discussões internas ao meio artístico, o que faz indispensável uma incursão nas condições de possibilidade que se apresentavam - em termos de linguagem e de história das formas - aos artistas dos maiores centros brasileiros.

\section{Religação e contestação nas artes plásticas: poéticas políticas}

A crescente preocupação em transbordar o espaço da obra à realidade (ou, por outro lado, em trazer a realidade ao espaço da obra) e o também crescente desejo dos artistas em comentar as grandes mudanças do contexto brasileiro levam algumas produções artísticas, por esses tempos, a transcender as discussões normalmente simplificadas entre "figurativo" versus "abstrato". O termo figuração, tão facilmente associado à produção artística brasileira dos anos 60 , se de um lado é uma redução da diversidade daquele momento a um denominador comum e relativamente arbitrário, de outro é um termo polissêmico o suficiente para comportar uma gama imensa, e por vezes contraditória, de manifestações plásticas. A rigor, e eis o primeiro problema, o termo figura é tão amplo que se confunde à imagem ou à configuração com os quais, pelo muito que informam, pouquíssimo nos ajudam. ${ }^{12}$

Em termos mais restritos, no entanto, e segundo a teoria gestáltica, uma figura é todo elemento - não necessariamente visual - cuja estrutura e qualidade permite que se separe de um fundo (SANTAELLA, 2001, p. 226-227)

12 Lembro-me, por exemplo, de um texto de Jean-François Lyotard, Discurso: figura, riquíssimo em suas sugestões sobre a complexidade do ver, mas que peca pela desnecessária prolixidade com que remete a antigos conceitos através de neologismos confusos como figura-imagem, figura-forma e figura-matriz (LYOTARD, 1979, p. 274). 
- o que torna a figura, nesse sentido, uma unidade específica, que tanto pode ser a representação de um castelo quanto a de um triângulo. Nesse caso, tanto um Mondrian quanto um Vermeer trabalham, em suas obras, com figuras, sempre hierarquizadas dentro de uma certa lógica compositiva da pintura.

Numa outra perspectiva já bastante usual à história da arte, o termo figurativo surge consagrado como sendo indicador daquele comportamento plástico que procura representar por semelhança as coisas, os seres e as relações visuais conforme nos parecem ao sentido da visão - perspectiva essa que relega às obras não-figurativas uma acepção negativa um pouco arbitrária, ao defini-las, dessa maneira, como sendo aquelas manifestações artísticas em cuja superfície não se pode reconhecer a aparência das figuras tridimensionais opostas ao fundo do mundo visualmente real. Aqui, portanto, a figuração aparece como o processo de significação que nos oferece certas relações visuais onde podemos projetar nosso esquemas perceptivos e reconhecer pessoas, chinelos ou gatos (GOMBRICH, 1995, p. 195 et seq.), enquanto a abstração, por sua vez, é o "antiprocesso" que parece abster-se da tarefa de nos informar sobre a existência e as qualidades de tais figuras. ${ }^{13}$ De uma forma ou de outra, essa tipologia simplificada me parece aqui importante justamente por estar na base de generalizações recorrentes como as que demarcam, por exemplo, o reinado da figuração (nova-figuração, retomada da figuração, etc) nos anos 60 em oposição à abstração (sobretudo concretista) dos anos 50.

É evidente que, numa mirada mais ampla e pouco aprofundada, não há como contestar que a figuração, nesse sentido, aparece nas produções artísticas dos anos 60 com uma freqüência extraordinária, suplantando aos poucos, em termos de reincidência na produção artística brasileira, as diversas tendências não-figurativas. Não que haja a substituição mecânica de uma pela outra, ou sequer a hegemonia de qualquer manifestação artística, pois a diversidade, como disse, foi uma das marcas fortes do período. Acontece que, contrapostas a um passado recente (que parecia concluir a história da arte sob a égide nãofigurativa), as produções vinculadas à pop, à nova figuração ou ao neo-realismo tiveram, num dado momento, maior poder aglutinador, no Brasil, do que propostas como o minimalismo, a pop ou os color fields. As formas figurativas, facilmente reconhecíveis, tornam-se realmente freqüentes nas obras de grandes

13 Tal compreensão dicotômica, contudo, está calcada mais em critérios psicológicos e sócioculturais de receptividade do que propriamente em princípios formativos de espacialidade plástica, embora as duas coisas andem, evidentemente, muito próximas. De qualquer forma, em detrimento desse excesso de simplificação, essa separação entre formas abstratas e figurativas está demasiado enraizada na cultura artística e na historiografia especializada para que aqui, em espaço tão exíguo, se possa avaliar-lhe mais profundamente. 
artistas como Wesley Duke Lee, Maurício Nogueira Lima e Rubens Gerchman, onde identificamos, de fato, pessoas, sapatos e estádios de futebol, elementos indistinguíveis em qualquer pintura tachista ou concreta.

Ocorre que quando afirmo que a produção artística dos anos $60 \mathrm{em}$ geral transcendeu a aporia abstração/figuração, não estou negando que a forma figurativa tenha reaparecido com força entre nós, mas por outro lado - e ampliando a questão -, estou apenas propondo que a noção de figuração possa ser entendida como um vigoroso sintoma da cultura artística daquele momento. $\mathrm{O}$ ato de figurar, seja entendido como o ato de representar figuras reconhecíveis ou como a ação de contrapor elementos à informidade de um fundo, parece-me oriundo de uma vontade de religação do mundo autônomo da obra com a complexidade do mundo cotidiano. O desejo de acrescer potencialmente aos problemas estéticos (atinentes ao trabalho específico do artista) toda a gama de problemas heterônomos talvez seja o motor dessa relação onde o artista, no perigoso equilíbrio entre fazer ou não arte, abre um veio discursivo coloquial no ventre de sua produção. Ao contrário do que ocorria na obra de arte ilusionista, onde se explorava a "aparência da eventual reconciliação da arte com a experiência heterogênea" (ADORNO, 1982, grifos meus), e ao contrário igualmente do projeto heróico-moderno de autonomia absoluta do estético, no processo de religação prevalece a admissão dos "escombros da experiência, sem aparência" (muito embora Adorno não estivesse pensando exatamente nesses termos). E, conforme creio, tal sentimento parece fruto de uma vontade estética $e$ ideológica de interferir, à maneira da obra, na ordem das coisas extra-estéticas, e da mesma forma, de aceitar sem pudores a interferência dessas no processo de elaboração artística.

Dessa forma, é preciso notar que a simples retomada de uma figuração tradicional, entendida como representação naturalista e perspéctica, era uma atitude conservadora demais para ser posta em prática. ${ }^{14} \mathrm{E}$ se os artistas admitem a infiltração do gesto figurador na sua produção, não o fazem, é evidente, no sentido de um Velásquez ou de um Pedro Américo, mas com base em outros esquemas culturais. Assim, quando sugiro o termo "religação", simplesmente estou propondo que se o diferencie tanto do processo de "ligação" - entendido como disposição formativa convencional da relação afetiva entre o homem e o mundo, no

14 "Figuração tradicional" é aqui entendida como aquela intenção formativa mimética de representar na tela a visão que temos do mundo tridimensional, através de expedientes específicos como a perspectiva científica, a visão monocular e estacionária, o modelado por gradação de tons, o escorço, o sfumato, e que resulta, por assim dizer, numa arte ilusionista, dominante na história da arte ocidental do Renascimento ao final do século XIX (GOMBRICH, 1995, p. 295 et seq). 
sentido que Worringer dá a projeção -, quanto do impulso geral da abstração, também compreendido no sentido worringeriano..$^{15}$ Imbricados, portanto, em problemas sociais, culturais, políticos e estéticos de outra ordem, os novos resultados artísticos surgem tão distintos quanto inovadores. Vejamos alguns exemplos.

À primeira vista, Guevara (ilustração 1), de Cláudio Tozzi, surge como um retrato do conhecido guerrilheiro latino-americano. Num segundo momento, aos olhos mais treinados, a obra traz referências diretas ao sucesso da pop-art na Bienal de São Paulo de 1967. E, finalmente, num outro nível de avaliação, a pintura de Tozzi afasta-se da pop norte-americana tanto pelas declarações do próprio artista (que ingenuamente reduzia a pop americana a um movimento acrítico e despolitizado), quanto pela dimensão da própria obra (pois Guevara ainda guarda, de um lado, uma relação afetiva com o objeto representado e, de outro, a condição artesanal pouco presente na fatura de um Warhol ou de um Oldenburg). Contudo, se reconhecemos de pronto na obra certas figuras (como rosto, boina e casaco) e se estas dispõem-se sobre o fundo liso e amarelo da representação - o que faria de Guevara uma figuração-, é preciso notar que não estamos mais no espaço profundo do renascimento, a não ser por uma abstração (descuidada) do olhar. O tratamento plástico da obra independe da relação figura-fundo, o modelado por variação tonal inexiste, as marcas pessoais do ato de pincelar desaparecem e o colorido naturalista é completamente abandonado. A obra evoca menos o próprio Che Guevara do que o processo técnico-mecânico de impressão por cores de seleção, do qual reproduziamse incontáveis "Ches" naqueles anos. ${ }^{16}$ Desse modo a visível figuração da obra de Tozzi pode ser vista em diálogo com algumas motivações distintas, todas vinculadas àquela religação mencionada: os problemas políticos mais gerais do Brasil e da

15 WORRINGER, s.d. Em conhecida argumentação, Wilhelm Worringer, pensando numa teoria das formas nas artes plásticas, apontou a existência de dois impulsos artísticos distintos. O primeiro, a projeção, corresponderia à tendência geral em que certas sociedades representaram positivamente seu relacionamento com o mundo, sobretudo através das representações de ordem pretensamente realista ou naturalista. Já a abstração, em oposição ao primeiro impulso, equivaleria à tendência também geral em que algumas sociedades buscaram representações mais esquemáticas, graças principalmente a um desacordo fundamental entre o homem e o mundo. Apesar da riqueza dessa argumentação, confesso que não possuo grandes simpatias em pensar hegelianamente a história a partir de princípios ordenadores como esses - ao que estendo igualmente certas ressalvas a pensadores como Wölfflin. Apenas percebo que, para algumas manifestações artísticas dos anos 60 e 70, a religação possa surgir como uma categoria sugestiva de análise - embora de forma alguma como eixo determinante.

16 A quadricromia por seleção de cores é um método policromático de reprodução onde a imagem colorida é separada em suas três cores primárias - magenta, amarelo e ciano - e mais preto (CRAIG, 1980, p. 105-113). Resultado de certos avanços técnicos na área gráfica, tal processo torna acessível, ao cotidiano urbano dos anos 60 e 70, uma infinidade de informações visuais coloridas de alta definição, interferindo drasticamente na cultura visual em geral, e na dos artistas em particular, como se vê no caso da pop. 
América Latina, o olhar alterado pelos novos meios massivos de reprodução mecânica e as questões específicas da história das formas artísticas. ${ }^{17}$

Outro processo formativo geralmente associado às figurações dos anos 60 é aquele presente na obra Glu-glu-glu, de Anna Maria Maiolino (ilustração 2). Nesse trabalho ainda é possível reconhecer com facilidade certos elementos como o corpo humano, uma boca e diversas vísceras, bem como é possível perceber quais são os elementos figurados que se utilizam de outros como fundo ordenador, uma vez que a composição hierarquizada do espaço é aqui uma operação evidentemente proposital. O diferencial, entretanto, está na relativa coincidência entre o espaço simbólico e o espaço físico, já que nessa obra as figuras não são simplesmente representadas sobre um fundo fictício, e sim aplicadas, em toda sua corporeidade, sobre a tela e outros espaços.

Quando recorto algo da realidade e o fixo sobre uma tela, ainda estou tratando a tela como o fundo da nova figura que é, aí, o objeto recortado. Era esse o caso das primeiras colagens cubistas de Braque e Picasso, e é esse - mutatis mutandis - o princípio básico que rege o método de Glu-glu-glu. As coloridas figuras estofadas - que lembram vagamente os objetos moles de Claes Oldenburg - são construídas em separado, uma a uma, e posteriormente fixadas, segundo uma certa ordem discursiva, sobre três fundos hierarquizados. O disforme e sintético corpo azul está assentado sobre um sólido - uma meia-caixa - que lhe serve de fundo; já as vísceras, por sua vez, aparecem fixadas sobre uma outra prancha tridimensional, à maneira com que os desenhos de biologia dispõem uma representação esquemática dos órgãos humanos sobre o papel dos livros didáticos; e todo esse conjunto de coisas espraia-se, ainda, sobre o espaço mais amplo da tela, que por seu lado assume, em relação a esses elementos, a condição de anteparo, no sentido que lhe dá Alberto Tassinari. ${ }^{18}$

17 Mesmo que seja somente para comprovar a ressalva que há pouco escrevi, não resisto a mencionar aqui uma curiosa passagem colhida no seio da fabulosa Teoria estética de Adorno, e que ilustra muito bem as restrições que o pensador alemão guardava frente a uma parcela da arte que era, então, em fins dos anos 60 , sua contemporânea: "o fato de quadros radicalmente abstratos poderem ser expostos sem escândalos nas galerias não justifica nenhuma restauração da arte figurativa que agrada a priori, mesmo se se escolhe Che Guevara para o fim de obter a reconciliação com o objeto" (ADORNO, 1982, p. 239 - sem grifos no original).

18 Como sabemos, foi um artista e tratadista do Renascimento italiano, Leon Battista Alberti, quem primeiro sugeriu, em seu tratado Della pittura, de 1436, que a arte ilusionista funcionaria como uma janela através da qual nós contemplamos o mundo visível (ALBERTI, 1989). Assim como também sabemos que foi Leonardo da Vinci quem deu substância a essa idéia, dizendo que a "perspectiva nada mais é do que ver um lugar através de uma vidraça transparente, na superfície da qual os objetos que estão do outro lado devem ser desenhados" (Leonardo apud GOMBRICH, 1995, p. 318). Dürer, inclusive, realizaria esses experimentos na prática, criando verdadeiras máquinas óticas de representação pictórica. Entretanto, em contraposição à idéia ilusionista de pintura como janela, Alberto Tassinari sugere que o pintor moderno vê a pintura de outra forma, como um anteparo, opaco, sobre o qual o artista deixa ver certas marcas de suas ações (TASSINARI, 2001). Para uma crítica da generalização do conceito de anteparo, cf. o meu texto "A norma de Tassinari", FREITAS, 2002. 
As referências metafóricas a respeito do homem massificado e politicamente desprovido do poder de reação frente ao que é obrigado a "engolir" só se tornam importantes se derivadas do poder de figurar essas questões de acordo com as possibilidades inerentes ao trabalho formativo da arte. Embora seja "contestadora", Glu-glu-glu assume e resolve sua religação com questões extra-estéticas por meio de problemas contemporâneos de uma história das artes visuais e não simplesmente ilustrando, via figuração tradicional, os dilemas que afligem o sujeito-artista.

Desse modo, no momento em que alguns artistas questionam a validade da tela como suporte tradicional, o problema já está dado. Dando sequiência a uma certa tendência em rever os posicionamentos mais ortodoxos do concretismo dos anos 50, Waldemar Cordeiro, em obras como Subdesenvolvido (ilustração 3), apropria-se de alguns elementos da realidade e os fixa - como numa colagem cubista - a uma base que lhe serve de fundo, num processo formativo muito próximo ao de Glu-glu-glu. As semelhanças, no entanto, ficam por aí, dando, em seguida, lugar a algumas diferenças fundamentais que residem em Subdesenvolvido. Primeiro, que os elementos que surgem distintos do fundo - as figuras, portanto - não são resultado do mesmo trabalho transformativo do artista como o eram as vísceras na obra de Maiolino ou a figura de Guevara na pintura de Tozzi; são fragmentos de móveis, fabricados em série pela indústria, apropriados do mundo real pela vontade do artista, ligeiramente modificados e por fim apresentados no espaço da obra - ou, conforme reza o discurso da tradição moderna da arte, são ready-mades retificados. ${ }^{19}$

Em segundo lugar, a base sobre a qual são assentados tais elementos não é mais uma tela - o suporte mais freqüente à pintura desde o Renascimento -, e sim um outro fragmento de móvel, no caso, uma porta de armário, o que implica em não diferenciar - em matéria ou densidade - o suporte da técnica, divisão também tradicional pela qual se prevê, por exemplo, que a trama de uma tela de linho é fisicamente distinta da viscosidade da tinta a óleo. Dessa maneira, aventa-se a inversão de tarefas cognitivas na medida em que se hoje a mesa e a cadeira estão pregadas na pequena porta, não temos mais certeza se amanhã

19 No ready-made talvez esteja uma das mais fundas raízes do gesto antiinstitucional vanguardista. Na poética pessoal do artista francês Marcel Duchamp, um ready-made corresponde à apropriação intencional de um objeto industrializado por um artista, no que se transforma tal objeto utilitário num "objeto de arte" (e por isso mesmo de crítica à noção burguesa de arte), pela simples recontextualização do mesmo. Quando o ready-made, além da pura apropriação, sofre algumas interferências, diz-se que é um ready-made retificado. "Em alguns casos os ready-made são puros, isto é, passam sem modificações do estado de objetos de uso ao de 'antiobras de arte'; outras vezes sofrem retificações e emendas, geralmente de ordem irônica e tendente a impedir toda confusão entre eles e os objetos artísticos" (PAZ, 1997, p. 19). 
a cadeira ou a mesa não servirão de suporte - e, portanto, de fundo - à própria portinhola. A relação figura-fundo é desequilibrada (bem como a divisão pintura/ escultura) e surge então a terceira diferença apontada por Subdesenvolvido: a denúncia da verticalidade da pintura.

A relação fenomenológica com a posição ereta e civilizada do homem e todo seu estatuto de imanente racionalidade são questionados por obras como essa, não tão infrequientes nos anos $60 .{ }^{20}$ Subdesenvolvido, portanto, é um belo exemplo de como, num certo ambiente de sugestões, alguns artistas puderam traduzir problemas gerais - sociais, políticos - em questões de formatividade e de linguagem, pois que participavam tanto das discussões estéticas quanto das políticas de seu tempo. Ou seja: se essa obra de Cordeiro, de um lado, entra com uma problemática atual ao sugerir tanto a pobreza arruinada do cotidiano brasileiro quanto a possibilidade efetiva de expressão artística povera (pobre) nesse contexto, de outro, faz acompanhar a esses resíduos do mundo social algumas preocupações mais radicais do mundo das formas artísticas, sem qualquer conservadorismo. ${ }^{21}$

Mesmo partindo de preocupações de outra ordem, Hélio Oiticica - um dos mais conseqüentes artistas dos anos 60 - chega a abordar alguns problemas similares em suas produções dessa mesma época. Unindo, à sua maneira, alguns procedimentos críticos dadaístas com a vocação construtiva oriunda do concretismo, o artista chega igualmente tanto à superação da dicotomia pintura/ escultura quanto à problematização radical da relação figura/suporte, tudo imerso num denso caldo crítico permeado à mítica sociocultural dos morros cariocas. Tendo integrado o movimento neoconcreto, Hélio parte das questões do não-objeto de Gullar para repensar a arte como integração efetiva entre obra e contexto, transformando a religação numa categoria central, inserindo a participação do corpo - e não apenas do olho - na obra. Seus bólides (ilustração 4) são proposições plurisensoriais onde materiais diversos - como areia, madeira, vidro, plástico ou pigmentos - são apropriados, mesclados e dispostos à

20 O crítico norte-americano Leo Steinberg sugeria, já em 1968, que a idéia de rompimento com a verticalidade da pintura poderia funcionar como um eixo central de análise à criticidade da arte contemporânea (STEINBERG, 1997). O artista Robert Rauschenberg, por exemplo, num gesto semelhante ao de Cordeiro, prendera uma cadeira na superfície da pintura, em sua obra Pilgrin, de 1960.

21 Subdesenvolvido é um dos conhecidos popcretos de Waldemar Cordeiro, linha poética que buscava levar os problemas do concretismo (ao lado de Augusto de Campos) de encontro a certos procedimentos da pop. Na leitura de Daisy Peccinini, "ambos, Cordeiro e Augusto de Campos, refletiam em seus popcretos o momento político, especialmente difícil, através de meios de efeito agressivo ou provocativo. Esses fragmentos de realidades denunciavam a alienação, o consumismo, a miséria e o autoritarismo. Nos quadro-montagens de Waldemar Cordeiro, os fragmentos de objetos têm aspecto decadente, corroído, arruinado, e títulos sugestivos como A-Brasão, Subdesenvolvido, Liberdade e Diálogo democrático" (PECCININI, 1999, p. 53). 
manipulação do espectador-participante. $O$ retiniano perde sua condição central no império das formas artísticas, os elementos apropriados e transformados pelo artista (como a mesa e a cadeira no caso de Subdesenvolvido) não são mais assentados sobre uma base ou um suporte e o "fundo" da obra confundese, assim, ao espaço do mundo, o entorno cotidiano. E, finalmente, esses elementos apropriados pelo artista deixam de se destinar à contemplação do receptor e demandam pela sua manipulação e experiência corpórea mais ampla. Um problema de linguagem, assim, se torna um problema político (ou num "exagero político", como quer Paulo Sérgio DUARTE (1998, p. 60), pois desse modo só haverá arte se, de um lado, houver a interação ativa de alguém, e de outro, se os templos consagrados destinados à acumulação e a exposição de obras previstas à contemplação ruírem. Segundo essa perspectiva, portanto, ou a arte se liberta de instituições como o museu, o salão e a Bienal, ou deixa de ser arte. $\mathrm{O}$ ato de nomeá-las, as coisas do mundo em comum, como proposições artísticas (ou antiartísticas), mora no cerne das condutas antiinstitucionais sintetizadas pela noção stricto sensu de vanguarda. Algumas palavras de Oiticica podem ser esclarecedoras.

Pretendo estender esse sentido de "apropriação" às coisas do mundo com que deparo nas ruas, terrenos baldios, os campos, o mundo ambiente, enfim - coisas que não seriam transportáveis, mas para as quais eu chamaria o público à participação - seria isso um golpe fatal no conceito de museu, galeria de arte etc., e ao próprio conceito de "exposição" - ou nós o modificamos ou continuamos na mesma. Museu é o mundo; a experiência cotidiana (...) Tenho um programa, para já, "apropriações ambientais". ${ }^{22}$

Numa certa altura, sobretudo a partir de meados dos 60, vão se tornando mais freqüentes proposições radicais como esta que, nas palavras sintéticas de FAVARETTO (1997), "celebravam a propalada morte da arte, rompiam a hegemonia do projeto construtivo e problematizavam o circuito". A primeira grande manifestação coletiva brasileira com intenções declaradas de vanguarda, e que reuniu artistas de São Paulo, do Rio de Janeiro e de Paris, foi a mostra Opinião 65. 


\section{As vanguardas brasileiras em tempos de radicalização}

Inaugurada no Museu de Arte Moderna do Rio de Janeiro em 12 de agosto de 1965, a exposição Opinião 65 contou com 30 participantes e foi inspirada no show musical Opinião, realizado em Copacabana no final de 1964. O clima de contestação política esparramou-se de uma Opinião à outra, fazendo da exposição no MAM-RJ um cenário complexo onde borbulhavam temas políticos, figurações e proposições de vanguarda - numa interessante síntese do período. É nessa mostra, inclusive, e de acordo com Paulo Sérgio Duarte, que "pela primeira vez, nas artes plásticas, a questão política e a crítica social apareciam integradas às novas linguagens e não associadas aos 'realismos', como eram freqüentemente tratadas pelos artistas 'oficiais' da esquerda" (DUARTE, 1998, p. 34-35). Artistas franceses vinculados à nova-figuração e à figuração narrativa da Escola de Paris dividiam o espaço com alguns popcretos de Waldemar Cordeiro e com Programação para um assassinato, de Antonio Dias, reforçando o ar polêmico do evento, uma aparência que já na época se vislumbrava. "O calor comunicativo social da mostra, sobretudo da jovem equipe brasileira, era muito mais efetivo. Havia ali uma resultante viva de graves acontecimentos que nos tocaram a todos, artistas e não-artistas da coletividade consumidora cultural brasileira", apontava o trotskista e crítico de arte Mário PEDROSA (1975, p. 101). O próprio Ferreira Gullar veria o valor positivo, de transgressão política e estética do evento: "de fato essa exposição revela que algo novo se pronuncia no próprio título da mostra: os pintores voltam a opinar! Isto é fundamental." 23

Quando Hélio Oiticica, afastado do meio artístico após a dispersão neoconcreta (PECCININI, 1999, p. 113), irrompe em Opinião 65 com seus Parangolés (ilustração 5), a vanguarda, a idéia de participação, a preocupação política e, conseqüentemente, a religação entre a espacialidade da arte e da vida são levadas ao extremo. Nessas obras - como é bem sabido - a própria idéia tradicional de obra, enquanto materialidade espacial permanente, é questionada, uma vez que os Parangolés são simplesmente capas coloridas, de tecido ou pano, que só existem, segundo seu autor, como proposição artística, se aquele que lhes "veste" estiver disposto a construir o ambiente da obra no momento em que constrói e ocupa, no tempo, o espaço do mundo. O estímulo à fantasia, assim, ao não resultar num objeto e ao somente existir, enquanto proposta

23 GULLAR, Ferreira. Opinião 65. Arte em revista, São Paulo, n. 2, maio/ago. 1979. p. 22. 
poética, no instante efêmero em que a mente a concebe, impede a formação de um registro que possa ser comercializado em galerias ou institucionalizado em acervos, da mesma forma que impulsiona o homem - enquanto corpo e consenso - à condição de elemento "figurado" no espaço que lhe envolve. Arte e política surgem, assim, numa utopia indivisível.

Para Opinião 65, Oiticica preparou uma espécie de "parangolé coletivo" (conforme expressão de Frederico Morais), levando ao Museu de Arte Moderna diversos passistas da Escola de Samba da Mangueira que "vestiam" suas "capas" e "estandartes" como se fossem adereços carnavalescos. Rubens Gerchman descreve o acontecimento:

Foi a primeira vez que o povo entrou no museu. Ninguém sabia se Oiticica era gênio ou louco e, de repente, eu o vi e fiquei maravilhado. Ele entrou pelo museu adentro com o pessoal da Mangueira e fomos atrás. Quiseram expulsá-lo, ele respondeu com palavrões, gritando para todo o mundo ouvir: "É isso mesmo, crioulo não entra no MAM, isto é racismo". E foi ficando exaltado. Expulso, ele foi se apresentar nos jardins, trazendo consigo a multidão que se acotovelava entre os quadros (GERCHMAN apud MORAIS, 1995, p. 282).

De um lado, a denúncia do elitismo institucional escapa ao campo da retórica combativa e se torna demonstração efetiva ao confrontar, num gesto estético-ideológico amplo, os limites diversos que realmente separam o popular do erudito, o morro do museu. De outro, os flexíveis limites da arte são mais uma vez testados no momento em que a participação do espectador enquanto dado construtor da obra no espaço real pede que o tempo seja incluso no universo do objeto plástico - e como sabemos, várias são as proposições artísticas dos anos 60 que apontam no sentido da inclusão da temporalidade nas artes plásticas (GLUSBERG, 1987, p. 25-35). Na Europa ou na América inclusive no Japão (grupo Gutai) e no próprio Brasil (com Lygia Clark) manifestações como o happening, como os "parangolés" (ou mesmo como a arte cinética) transcendem o habitual predomínio da espacialidade, carregando a noção de obra de encontro à de ação ou acontecimento, num ímpeto contestador muitas vezes subversivo e antiinstitucional.

Paralelo à crescente diversidade de formas de expressão no campo artístico nacional (motivada, sobretudo, pela grande variedade de "ismos" internacionalizados que aportam em solo brasileiro via Bienais de São Paulo ou 
outras grandes exposições), um número considerável de artistas demonstra-se cada vez mais preocupado tanto com as questões da figuração e de uma vanguarda nacional quanto com os mais diversos problemas sociais, culturais, políticos e econômicos que surgem durante os primeiros anos do regime militar. Ainda assim, e como se sabe, o envolvimento efetivo do artista plástico em organizações políticas é, nesses tempos, muito pequeno, ficando restrito, de um modo geral, a atitudes isoladas e pouco recorrentes. ${ }^{24}$ Contudo, em termos mais amplos, não são poucos os artistas que simpatizam com certas causas mais fluidas e menos sistemáticas de um pensamento de esquerda no Brasil, o que se evidencia, inclusive, em certas obras do período, embora não haja - que fique bem claro - qualquer forma de ligação mecânica prevista a priori entre o posicionamento político do produtor cultural e as eventuais considerações políticas explícitas em suas produções. ${ }^{25}$

Entre 1964 e 1968, nas diversas áreas da produção cultural brasileira como se disse - há um adensamento crítico de oposição e o recrudescimento de uma espécie de arte de contestação - em detrimento do poder repressivo do regime autoritário - de acordo com o estado de anomalia já mencionada por Schwarz. Nas artes plásticas, dentro de seus limites e especificidades, e considerados alguns exemplos particulares, a situação mantém algumas semelhanças.

Partindo de propósitos semelhantes aos da mostra carioca Opinião 65, Waldemar Cordeiro realiza a Propostas 65, em São Paulo, exatamente no mesmo ano em que o combativo Ferreira Gullar assume os comentários sobre artes plásticas na Revista Civilização Brasileira, conhecido veículo arregimentador de debates sociológicos sobre os problemas da política e da cultura no país. No ano seguinte ocorrem Opinião 66 e Propostas 66, dando continuidade ao projeto iniciado pelas edições anteriores; Gerchman pinta sua

24 Como nos demonstrou Marcelo Ridenti, saltar dos pincéis e das letras aos fuzis, mesmo no período mais duro da repressão (pós-AI-5), não era algo comum no meio artístico. Partindo dos "dados estatísticos construídos com base nos processos levantados pelo BNM junto à Justiça Militar", o sociólogo afirma que "a presença de artistas nas organizações de esquerda era ínfima - 24, dentre 3.698 denunciados com ocupação conhecida. Vale notar que as organizações armadas urbanas, mais que as outras, contaram com 'artistas': nelas, participaram 18 artistas $(0,9 \%$ do total de 1.897 supostos integrantes dos grupos armados urbanos típicos), enquanto nas demais participaram 6 artistas $(0,3 \%$ dentre 1.801 envolvidos em processos dos demais grupos de esquerda)" (RIDENTI, 1993, p. 73). É preciso relembrar, no entanto, que numa pesquisa quantitativa como essa, o problema de se definir o que seria ou não, nesse contexto, um "artista", é um problema que escapa da alçada da sociologia, justamente ao acusar seus limites epistemológicos.

25 É preciso lembrar o caso do expressionismo abstrato norte-americano que, mesmo tendo em suas origens alguns artistas e intelectuais de orientação política de esquerda, foi um movimento que em geral não permeou suas produções artísticas com evidentes narrativas políticas, chegando inclusive a ser associado à retórica imperialista da política cultural norte-americana do pós-guerra (HARRIS, 1998). 
Lindonéia; a galeria Relevo apresenta a exposição Supermercado 66; e a galeria de vanguarda G-4 (uma garagem reformada) inicia suas atividades com a exposição-happening Pare, de Antonio Dias, Rubens Gerchman, Vergara, Escosteguy e Oiticica, onde, entre outras obras, havia a proposição de Vergara resumida num furo na parede e um cartaz ao lado pedindo para que as pessoas olhassem através do furo. Do outro lado lia-se algo assim: "ao invés do Sr. ficar nessa atitude ridícula, olhando nesse buraco, por que não toma uma atitude em relação às coisas que estão acontecendo em sua volta, etc e tal" (HOLLANDA, 1982). O grupo Rex inicia suas atividades; e Antonio Henrique Amaral, com seus monstruosos generais, tece os primeiros comentários explícitos à ditadura. A partir das discussões surgidas em Propostas $66^{26}$ - sobretudo dos pronunciamentos de Frederico Morais e Hélio Oiticica - estabelecem-se as bases estético-ideológicas para a idéia de uma possível vanguarda brasileira. A idéia, por si só - é claro - não serve para resolver as contradições do meio artístico brasileiro de então - até porque ela sustenta, de diversas maneiras, um certo ar discriminatório frente as manifestações artísticas que não se lhe adequassem (e não eram poucas) -, mas serve para expor com razoável clareza um determinado estado de espírito, certamente complexo, de vontade de combate. O radicalismo de certas tendências e propostas artísticas do período, variavelmente dispersas, aparece sintetizado, de maneira programática, no manifesto intitulado Declaração dos princípios básicos da vanguarda, documento básico para o estudo do período.

Além da presença dos críticos Mário Pedrosa, Frederico Morais e Mário Barata, a Declaração... trazia entre seus signatários as marcas de convergência entre a geração neoconcreta (Oiticica, Lygia Clark e Lygia Pape) e os jovens artistas das novas vanguardas (como Zílio, Vergara, Dias, Gerchman, entre outros). Junto à elaboração do manifesto, surgiu a idéia de uma exposição nacional de vanguarda, concretizada no mesmo ano (1967) numa coletiva de cerca de 50 artistas realizada no MAM-RJ: a Nova objetividade brasileira. Essa exposição - que no dizer da historiadora Daisy Peccinini "fez o inventário da nova vanguarda que se propunha nacional" (PECCININI, 1999, p. 141) - foi a última grande manifestação coletiva realmente propositora da década (e da próxima), tendo sido impulsionada, em sua arregimentação, tanto pela vontade

26 Evento organizado novamente por Waldemar Cordeiro, em São Paulo (Biblioteca Municipal), que com o apoio da Secretaria Municipal de Cultura dividiu-se numa série de importantes seminários ministrados por artistas e intelectuais de destaque como Otávio Ianni, Vilanova Artigas, Mário Schenberg, Mário Pedrosa, Mário Barata, Jayme Maurício, Frederico Morais, Oiticica, Aracy Amaral entre outros (PECCININI, 1999, p. 133). 
de demarcar um território de expressão radical nas linguagens, quanto pela aspiração mais ampla e genérica de desobediência e rebeldia ao regime militar, criando, assim, boas condições para o desenvolvimento plural do gesto transgressor. Essa vontade de combate - prevista pela Declaração... e posta em ação na Nova objetividade brasileira - aparece brilhantemente condensada no mini-manifesto apresentado por Oiticica no catálogo da exposição, onde se prescrevia à vanguarda brasileira as seguintes características:

1 Vontade construtiva geral

2 Tendência para o objeto ao ser negado e superado o quadro de cavalete

3 Participação do espectador: corporal, tátil, visual e semântica

4 Abordagem e tomada de posição em relação aos problemas políticos, sociais e éticos

5 Tendência para uma arte coletiva e conseqüente abolição dos ismos

6 Ressurgimento e novas formulações do conceito de antiarte (OITICICA apud MORAIS, 1995, p. 296).

A negação, de um lado, e a construção, de outro, são os gestos que resumem as angústias e as utopias não só dos artistas ou mesmo da vanguarda brasileira de então, mas de toda uma geração de intelectuais preocupada tanto com os problemas políticos gerais do país quanto com os problemas específicos de sua produção cultural. O gesto construtivo, herdado do pensamento concreto e de uma certa aspiração desenvolvimentista e democratizadora (daí as noções de participação, coletividade, tendência ao objeto) corre paralelo à crítica pela negatividade, herdeira direta tanto das neovanguardas (revisão de Duchamp, antiarte, abolição dos "ismos", fim do quadro de cavalete) quanto do desejo de superação de nosso arcaísmo, de nossas injustiças sociais e do autoritarismo hegemônico militar, imperialista e burguês que grassava pelo Brasil.

Entre 1967 e 1968, respirando toda a problemática histórica deste período brasileiro, surgem algumas das produções artísticas mais abertas ao engajamento político explícito. Antonio Manuel lida diretamente com o imaginário da violência de rua dos movimentos estudantis (FREITAS, 2003, p. 75-94); Hélio Oiticica homenageia, em Cara de cavalo, o criminoso e amigo (de apelido homônimo) brutalmente assassinado pelo Esquadrão da Morte; Tropicália - ambiental proposto também por Oiticica na mostra Nova objetividade brasileira - refigura as fantasmagorias de brasilidade na arte e na 
cultura, Antonio Henrique Amaral produz a ácida série de xilogravuras $O$ meu e o seu; a arte ganha as ruas em Arte no Aterro, sob a coordenação de Frederico Morais; Carlos Zílio, no limite entre a arte e a militância, constrói a obra-marmita Lute; enquanto no Rio e em São Paulo no evento Bandeiras na praça, artistas como Glauco Rodrigues, Pietrina Checcacci, Nelson Leirner, Tozzi e o próprio Oiticica expõem em praça pública suas provocadoras obras-bandeiras. ${ }^{27}$

Não tarda, portanto, para que a violência e a censura do regime, mais freqüentes em áreas de maior visibilidade como o teatro, o cinema e a música popular, deite igualmente seus braços sombrios sobre o campo artístico. $\mathrm{O}$ depoimento de Frederico Morais, em seu livro Artes plásticas: a crise da hora atual, é elucidativo:

Os primeiro arrufos com a censura ocorreram no IV Salão de Brasília, exatamente dois anos antes [1966]. Mas a pronta reação do júri impediu que fossem retirados trabalhos de Cláudio Tozzi e José Aguilar considerados políticos. No 3. ${ }^{\circ}$ salão de Ouro Preto o júri sequer pode ver algumas gravuras inscritas, previamente retiradas. Contudo, o primeiro conflito realmente grave com a censura ocorreu na II Bienal da Bahia, inaugurada alguns dias antes do Ato Institucional [ ${ }^{\circ}{ }^{\circ}$ 5]. No discurso inaugural de abertura o então governador Luiz Vianna Filho afirmou que "toda arte jovem tem de ser revolucionária" e que "a liberdade caracteriza a arte". No outro dia, entretanto, a Bienal foi fechada, presos seus organizadores, seguindo-se a retirada de vários trabalhos considerados eróticos e subversivos. Os incidentes provocaram tímidos protestos das entidades representativas dos artistas e críticos, no país, e manifestações enérgicas no exterior, incluindo da Associação Internacional de Críticos de Arte. Como consequiência, a Bienal da Bahia encerrou precocemente sua carreira (MORAIS, 1975, p. 101-102).

A situação ainda se agravaria depois de 13 de dezembro de 1968 quando, em resposta à instabilidade política e aos movimentos sociais dos últimos meses, e acuado pelos militares radicais em represália à decisão do Congresso em proteger o deputado "Marcito" (Márcio Moreira Alves), o presidente Costa e Silva leva à votação extraordinária e à aprovação o Ato

27 "Participam do evento bandeiras de Hélio Oiticica (a foto já conhecida de Cara de cavalo morto e a frase 'seja marginal, seja herói'), Samuel Spiegl (propondo a candidatura de Tomé de Souza à presidência do Brasil), Luiz Gonzaga (Tio Sam), Glauco Rodrigues ('Yes, nós temos banana'), Pietrina Checcacci, Cláudio Tozzi ('Guevara, vivo ou morto'), entre outros” (MORAIS, 1995, p. 300). 
Institucional n. ${ }^{0} 5 .^{28}$ No ano seguinte, em 1969 e já em plena vigência do AI-5, embora se generalizasse um espírito de autocensura, a situação de conflito com os órgãos censores fica ainda pior, levando ao mais grave incidente envolvendo as artes plásticas no país: a proibição, pelo governo, da exibição no MAM-RJ das obras escolhidas para representarem futuramente o Brasil na VI Bienal de Paris. Niomar Moniz Sodré, então na presidência do MAM, assim descreveu o caso:

A exposição já estava montada e os convites distribuídos para a abertura às $18 \mathrm{~h}$. Eu estava no Correio da Manhã, quando, às 15h, recebi telefonema de Madeleine Archer dizendo que militares haviam entrado no Museu e fechado a porta que dava acesso à mostra, sob a alegação de que era uma exposição subversiva. A diretoria funcionava no bloco-escola. Os militares voltaram em seguida, desmontaram a exposição, colocando as obras no depósito do Museu. Eu, Mário Pedrosa, Maurício Roberto e Madeleine Archer ficamos conversando até tarde da noite, no museu. Antes de ir embora, eu peguei o trabalho de Antonio Manuel e o levei direto para o Correio da Manhã e o escondi entre as almofadas de um sofá, receosa de que os militares invadissem também o jornal. Na Bienal de Paris, o espaço reservado ao Brasil ficou vazio, com o objetivo de mostrar que a exposição fora censurada. ${ }^{29}$

Os resultados desses incidentes são desastrosos. De um lado, Mário Pedrosa, na qualidade de presidente da Associação Brasileira de Críticos de Arte (ABCA), publica uma nota indignada lembrando que a Constituição vigente

28 Com vinte e dois votos a um, o Ato passou a vigorar, previsto inicialmente para durar apenas oito ou noves meses, mas com vigência efetiva de mais de uma década. Durante os próximos dez anos, seis senadores, 110 deputados federais e 161 estaduais, vinte e dois prefeitos e vinte e dois vereadores foram cassados, num universo de mais de mil e seiscentos cidadãos punidos. No campo da produção cultural, a ação da censura foi igualmente nefasta: 500 filmes, 450 peças de teatro, 200 livros, 100 revistas, 500 letras de música, dezenas de programas de rádio, uma dúzia de capítulos e sinopses de telenovela; todos parcial ou integralmente vetados (VENTURA, 1988, p. 263-286).

29 Niomar Sodré apud MORAIS, 1995: 307-8. Niomar Sodré, proprietária do jornal carioca Correio da Manhã e presa pelo DOPS em 1969, vivenciou alguns dos problemas mais críticos da censura no período. Leia-se, por exemplo, o que se publicou, em novembro de 1969, nas páginas do próprio Correio: “As autoridades de hoje, porém, não se detiveram nas medidas de força e de terror. A elas aliaram as perseguições econômicas. Ao natural receio que, em semelhante atmosfera, provocou o retraimento de numerosos anunciantes da área privada, somou-se ao veto da inserção em nosso jornal de anúncios que outros órgãos de imprensa repartições e empresas públicas. Era o bloqueio sem disfarces. A publicidade do Estado, financiada pelos contribuintes, representando $36 \%$ do total do mercado publicitário, foi sonegada maciçamente a uma instituição com quase 70 anos de relevantes serviços" (Correio da Manhã, 11 set. 1969 apud MARCONI, 1980, p. 40-41). 
não prevê nenhuma espécie de censura: "A ABCA não se sente autorizada a colaborar com os poderes públicos naquilo que é sua função específica: assegurar o nível mais alto dos valores artísticos, (...) mantendo ao mesmo tempo o princípio da liberdade de criação". ${ }^{30}$ De outro lado, fora do país, a repercussão tanto do fechamento da mostra no MAM-RJ quanto do documento da ABCA é enorme e negativa, dando início ao processo de boicote internacional à Bienal de São Paulo, o que acarretaria num grave prejuízo à cultura artística brasileira.

Fechavam-se os anos 60. 


\section{Referências}

ADORNO, Theodor W. Teoria estética. São Paulo: Martins Fontes, 1982.

ALBERTI, Leon Batista. Da pintura. Campinas: Unicamp, 1989.

AMARAL, Aracy. Arte para quê? a preocupação social na arte brasileira 1930-1970. São Paulo: Livraria Nobel AS, 1984.

BOSI, Alfredo. Dialética da colonização. São Paulo: Companhia das Letras, 1992.

BOURDIEU, Pierre. A economia das trocas simbólicas. São Paulo: Perspectiva, 1998. O poder simbólico. Lisboa: Difel, 1989.

BRITO, Ronaldo. Neoconcretismo: vértice e ruptura do projeto construtivo brasileiro. São Paulo: Cosac \& Naify, 1999.

BÜRGER, Peter. Teoria da vanguarda. Lisboa: Veja, 1993.

CANCLINI, Néstor Garcia. Culturas híbridas: estratégias para entrar e sair da modernidade. 3 ed. São Paulo: Edusp, 2000.

CRAIG, James. Produção gráfica. São Paulo: Mosaico; Edusp, 1980.

DUARTE, Paulo Sérgio. Anos 60: transformações da arte no Brasil. Rio de Janeiro: Campos Gerais, 1998.

DURAND, José Carlos. Arte, privilégio e distinção: artes plásticas, arquitetura e classe dirigente no Brasil, 1855-1985. São Paulo: Perspectiva/Edusp, 1989.

FAVARETTO, Celso. Das novas figurações à arte conceitual. In: RIBENBOIM, R. (Org). Tridimensionalidade. São Paulo: Itaú Cultural, 1997.

FREITAS, Artur. Arte e contestação: uma interpretação relacional das artes plásticas nos anos de chumbo - 1968-1973. Curitiba, 2003. 217 f. Dissertação (Mestrado em História) - Setor de Ciências Humanas Letras e Artes, Universidade Federal do Paraná.

A norma de Tassinari. Arte na crise. Anais do Encontro de Arte Visuais da UFRJ. Rio de Janeiro: UFRJ, 2002.

GOMBRICH, Ernst Hans. Arte e ilusão: um estudo da psicologia da representação pictórica. 3 ed. São Paulo: Martins Fontes, 1995.

GLUSBERG. Jorge. A arte da performance. São Paulo: Perspectiva, 1987.

GULLAR, Ferreira. Cultura posta em questão. Rio de Janeiro: Civilização Brasileira, 1963.

Etapas da arte contemporânea: do cubismo ao neoconcretismo. São Paulo: Nobel, 1999. 
HARRIS, Jonathan. Modernismo e cultura nos Estados Unidos. In: WOOD, Paul et al. Modernismo em disputa. São Paulo: Cosac \& Naify, 1998.

HOLLANDA, Heloísa Buarque de. Cultura e participação nos anos 60. São Paulo: Brasiliense, 1982.

LYOTARD, Jean-François. Discurso, figura. Barcelona: Gustavo Gilli, 1979.

MARCONI, Paolo. A censura política na imprensa brasileira: 1968-1978. São Paulo: Global, 1980.

MICELI, Sérgio. O papel político dos meios de comunicação de massa. In: SCHWARTZ, Jorge; SOSNOWSKI, Saúl. (Orgs). O trânsito da memória. São Paulo: Edusp, 1994.

MORAIS, Frederico. Artes plásticas: a crise da hora atual. Rio de Janeiro: Paz e Terra, 1975.

Cronologia das artes plásticas no Rio de Janeiro: 1816-1994. Rio de Janeiro: Topbooks, 1995.

NAPOLITANO, Marcos. Cultura brasileira: utopia e massificação (1950-1980). São Paulo: Contexto, 2001a.

. A arte engajada e seus públicos (1955-1968). Estudos históricos. Rio de Janeiro, n. 28, 2001b.

ORTIZ, Renato. Cultura brasileira e identidade nacional. São Paulo: Brasiliense, 1985. . A moderna tradição brasileira. São Paulo: Brasiliense, 1991. . Mundialização e cultura. São Paulo: Brasiliense, 1994.

PAZ, Otávio. Marcel Duchamp ou o castelo da pureza. São Paulo: Perspectiva, 1997. PECCININI, Daisy. Figurações Brasil anos 60: neofigurações fantásticas e neosurrealismo, novo realismo e nova objetividade. São Paulo: Itaú Cultural / Edusp, 1999.

PEDROSA, Mário. Mundo, homem, arte em crise. São Paulo: Perspectiva, 1975.

RIDENTI, Marcelo. O fantasma da revolução brasileira. São Paulo: Unesp, 1993.

SANTAELLA, Lúcia. Matrizes da linguagem e pensamento. São Paulo: Iluminuras, 2001.

SCHWARZ, Roberto. O pai de família. Rio de Janeiro: Paz e Terra, 1978.

STEINBERG, Leo. Outros critérios. In: GREENBERG, Clement. Clement Greenberg e o debate crítico. Rio de Janeiro: Zahar, 1997.

TASSINARI, Alberto. O espaço moderno. São Paulo: Cosac \& Naify, 2001.

VATTIMO, Gianni. O fim da modernidade: niilismo e hermenêutica na cultura pósmoderna. São Paulo: Martins Fontes, 2002. 
VENTURA, Zuenir. 1968: o ano que não terminou. Rio de Janeiro: Nova Fronteira, 1988.

WORRINGER, W. Abstraccion y Naturaleza. México: Fondo de Cultura Económica. s.d.

ZANINI, Walter. História geral da arte no Brasil. São Paulo: Instituto Walter Moreira Salles, 1983. 2 v. 